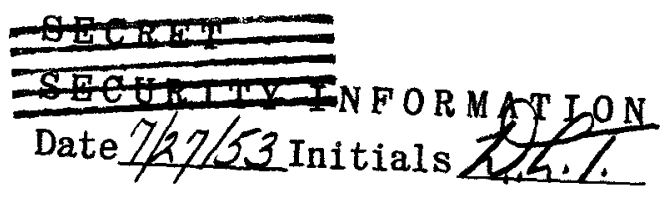

This Document Consists of 7 Pages This is Copy of $157 \mathrm{~A}$

MLM-808

Category - PHYsICS AND mathematrcs

\title{
UNCLASSIFIED
}

\section{A REDETERMINATION OF THE LATTICE \\ Parameters of POLONIUM}

BY

J.M. GOODE
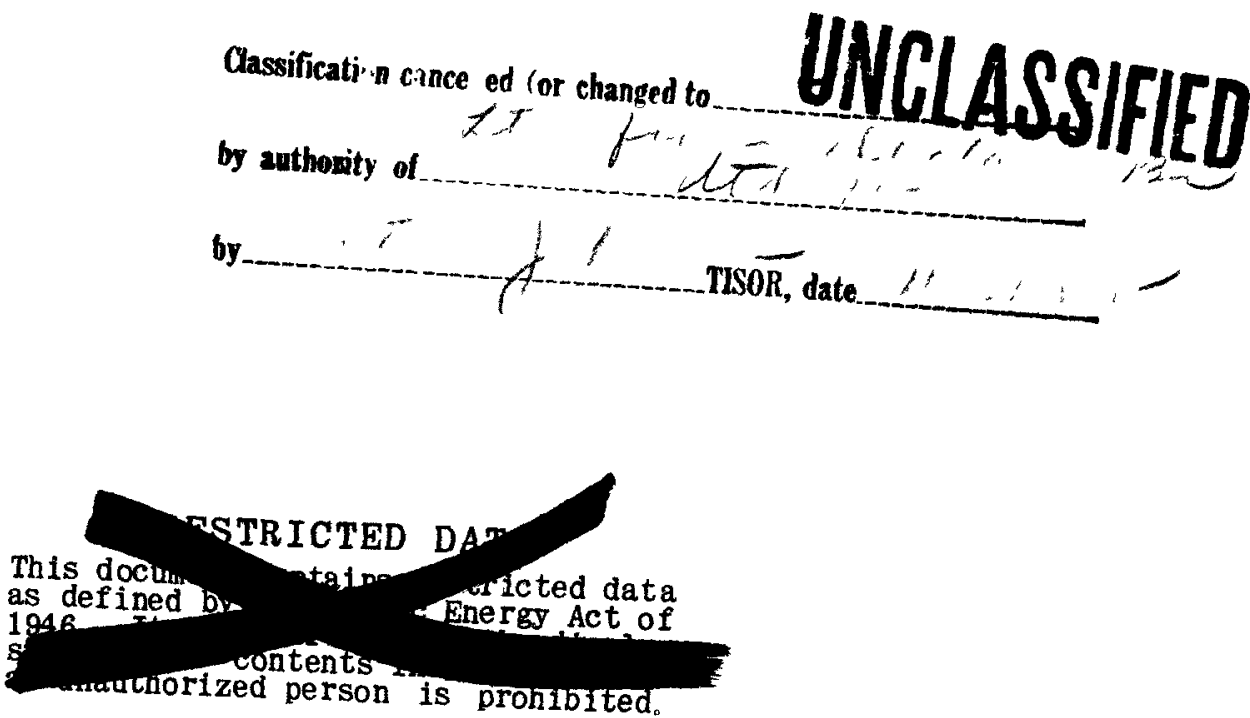

Bate: January 30
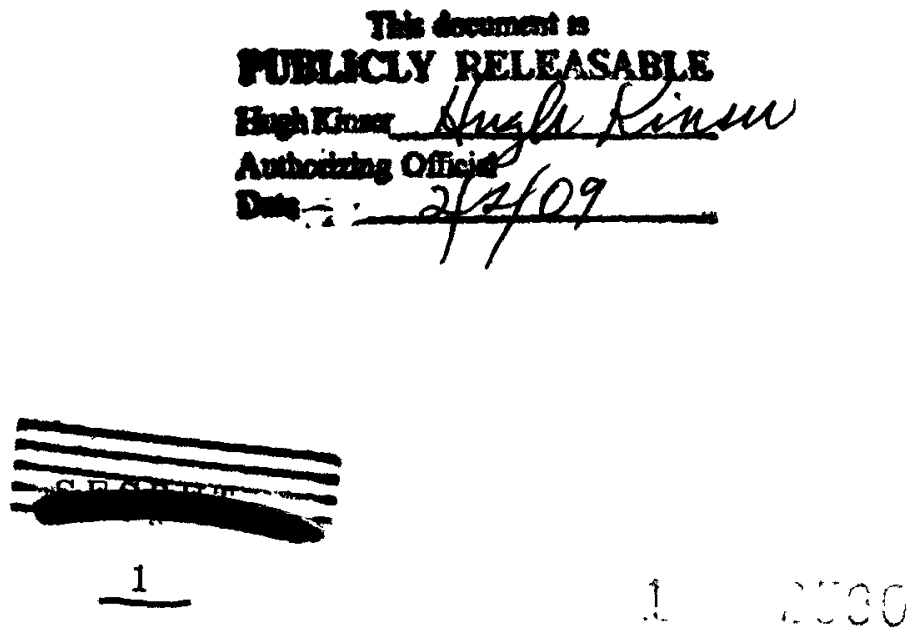


\section{DISCLAIMER}

This report was prepared as an account of work sponsored by an agency of the United States Government. Neither the United States Government nor any agency Thereof, nor any of their employees, makes any warranty, express or implied, or assumes any legal liability or responsibility for the accuracy, completeness, or usefulness of any information, apparatus, product, or process disclosed, or represents that its use would not infringe privately owned rights. Reference herein to any specific commercial product, process, or service by trade name, trademark, manufacturer, or otherwise does not necessarily constitute or imply its endorsement, recommendation, or favoring by the United States Government or any agency thereof. The views and opinions of authors expressed herein do not necessarily state or reflect those of the United States Government or any agency thereof. 


\section{DISCLAIMER}

Portions of this document may be illegible in electronic image products. Images are produced from the best available original document. 


\section{STANDARD DISTRIBUTION}

Mound Laboratory

through 28

AF Plant Representative, Burbank

AF Plant Representative Seattle

AF Plant Representative, Food $\circ$ Ridge

ANP Project office Fort Worth

Argonne National Laboratory

Armed Forces Special Weapons Project (Sandia)

Armed Forces Special Weapons Project, Washington

Army Chemical Center

Atomic Energy Commission, Washington

Battelle Memorial Institute

Bechtel Company

Brookhaven National Laboratory

Burean of Ships

Cal iforni a Besearch and Development Company

Carbide and Carbon Chemicals Company (C-31 Plant)

Carbide and Carbon Chemicals Company ( $K-25$ Plant)

Carbide and Carbon Chemicals Company (ORNL)

Carbide and Carbon Chemicals Company ( $Y=12$ Plant)

Chicago Patent Group

Chief of Naval Research

Columbia University (Havens)

Commonweal th Edison Company

Department of the Navy = op-362

Detroit Edison Company

Directorate of Research (WADC)

duPont Company. Augusta

Foster Theeler Company

General El ectric Company (ANPP)

General Electric Company Richi and

Goodyear Atomic Corporation

Hanford Operations office

I daho Operations office

Iowa State College

Kirtland Air Force Base

Knolls Atomic Power Laboratory

Los Al amos Scientific Laboratory

Massachusetts Institute of Technology (Kanfmann)

Monsanto Chemical Company

National Advisory Comittee for Aeronautics, Clevel and

29

30

31

$\mathbf{3 3}$

42

43

44

48

49

53

55

$\mathbf{5 7}$

65

69

70

71

73

74

75

76

83$$
87
$$$$
90
$$$$
94
$$

95

96

100

102

103

104

105

106

Naval Medical Research Institute

Naval Research Laboratory

New Brunswick Laboratory

New York Operations office

North American Aviation. Inc.

Nuclear Development Associates, Inc.

Patent Branch Washington

Pioneer Services \& Engineering Company

107

109

110

112

115

116

117

118

119

RAND Corporation

Sandia Corporation

Savannah River Operations office, Augusta

USAF Headquarters

$U_{\text {o }} S_{\text {. Naval Radiological Defense Laboratory }}$

UCLA Medical Research Laboratory (Warren)

University of California Radiation Laboratory, Berkeley

University of California Radiation Laboratory, Livermore

University of Rochester

Vitro Corporation of America

Wal ter Kidde Nuclear Laboratories, Inc。

Westinghouse Electric Corporation

Yale University

Technical Information Service, oak Ridge
120

121

122

123

124

125 through 129

130 through 132

133 through 134

135 through 136

137

138 through 141

142

143 through 157

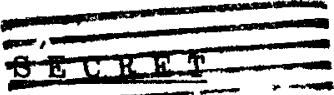




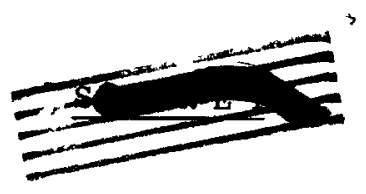

\title{
INTERNAL DISTRIBUTION
}

\author{
1. Carroll A. Hochwalt \\ 2. N。No To Samaras \\ 3. J。 J. Burbage \\ 4. R。 Ataniforth \\ 5. E。 Cocarthy \\ 6. J。 Eichelberger \\ 7. E。A。 Rembold \\ 8. D.L. Scott \\ 9. DoL。 TImma \\ 10. I, E, Bersuder \\ 11. J。 Heyd \\ 12. E。 S Spoerl \\ 13. R. d。Cote \\ 14. G A Essig \\ 13. A. Pish \\ 16. Jo M. Goode \\ 17. H. Ho Tal do \\ 18. Ko Kasschau, Office Res, and Med, Oak Ridge \\ 19. F。 Rowling, office Prod, and Eng, Oak Ridge \\ 20. J. Hoberson, Area Manager, AEC, Dayton, Ohio \\ 21. Central Files \\ 22. Central Files \\ 23. Central Files \\ 24. Central Files \\ 25. Central Files \\ 26. Central Files \\ 27. Central Files \\ 28. Central Files
}

Issued: AUG $7 \quad 1953$

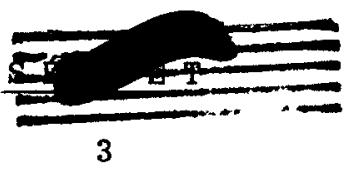




\section{UNCLASSIFIED}

MLM- 808

\section{ABSTRACT}

A more precise determination of the lattice parameters and $\mathrm{X}$-ray density of polonium has been made with the use of the extrapolation method of Bradley and Jay. The low-temperature simple cubic phase has a lattice parameter of

$\omega_{0}=3359 \pm 0.082 \mathrm{~A}$ and an $\mathrm{X}-\mathrm{ray}$ density of $9.196 \pm 0.006 \mathrm{gram}$ per cubic centimeter at $39 \mathrm{C}$. The high-temperature rhpmbohedral phase has lattice parameters of $a_{0}=3.366 \pm 0002 A, a=985 \neq 2$, and an $X$-ray density of $9398 \pm 0006$ gram per cubic centimeter at $39^{\circ} \mathrm{C}$.

\section{INTRODUCTION}

The crystal structure of polonium was first studied by M. A. Rollier, S. B. Hendricks, and L. R. Maxwell $1^{1}$ by means of electron diffraction. They interpreted the structure as monoclinic with $a_{0}=7.42 \mathrm{~A}, b_{0}=4.29 \mathrm{~A}, c_{0}=14.10 \mathrm{~A}$, and $\alpha=90^{\circ}$.

Later work was done by Maxwell and Beamer ${ }^{2}$ at Los Alamos in 1946. Their results indicated that polonium exists in two phases a low-temperature simple cubic phase with $a_{0}=3.345 \mathrm{~A}$ and a high-temperature simple rhombohedral phase with $a_{0}=3.359 \mathrm{~A}$ and $a=98^{\circ} 13^{\circ}$.

Diffraction studies of polonium carried out at Mound Laboratory have indicated that the lattice parameters obtained by Maxwell and Beamer are slightly in error. More correctly, the low-temperature phase has a lattice parameter of $a_{0}=3.359 \pm 0.002 \mathrm{~A}$ and the high-temperature phase has lattice parameters of $a_{0}=3.366 \pm 0.002 \mathrm{~A}$ and $\alpha=98^{\circ} 5^{\prime} \pm 2^{\prime}$ at $39^{\circ} \mathrm{C}$ 。

\section{METHODS AND RESULTS}

The X-ray samples used to refine the values of the polonium lattice parameters were prepared by a method similar to that used by Maxwell and Beamer. ${ }^{2}$ The polonium was purified by fractional volatilization in an evacuated fused-silica tube. The polonium was then volatilized Into a thin-walled, fused-silica X-ray capillary. Only patterns taken soon after preparation could be considered because of the rapid conversion of polonium to lead.

The data for the high-temperature or beta-polonium phase were taken from a total of five patterns obtained from three samples. The data for the low-temperature or alpha-polonium phase were taken from a total of four patterns from two samples. The history of these patterns is given in Table $I$.

\begin{tabular}{|c|c|c|c|c|}
\hline \multirow[b]{2}{*}{ SAMPLE } & \multicolumn{3}{|c|}{ PATTERN HISTORY } & \multirow[b]{2}{*}{$\begin{array}{l}\text { INTERNAL } \\
\text { STANDARD }\end{array}$} \\
\hline & PATTERN & $\begin{array}{l}\text { POLON I UM } \\
\text { DECAYED } \\
(\not)\end{array}$ & $\begin{array}{l}\text { POLON IUM } \\
\text { PHASE }\end{array}$ & \\
\hline 51 & 511 & $\frac{1}{2}$ & $\beta$ & NONE \\
\hline 59 & 59 i & $1 \frac{1}{2}$ & $\beta$ & $\mathrm{Ta}$ \\
\hline 59 & $59 \cdot 2$ & 4 & $\beta$ & $\mathrm{Ta}$ \\
\hline 68 & 68.1 & $\frac{1}{2}$ & $\beta$ & $\mathrm{Au}$ \\
\hline 68 & 682 & 1 & $\beta$ & $\mathrm{Au}$ \\
\hline 51 & 51.2 & 1 & $\alpha$ & NONE \\
\hline 51 & 512 & $1 \frac{1}{2}$ & $a$ & NONE \\
\hline 59 & 59 i & $q \frac{1}{2}$ & $a$ & $\mathrm{Ta}$ \\
\hline 59 & 592 & 4 & $\alpha$ & $\mathrm{Ta}$ \\
\hline
\end{tabular}


The patterns were taken with a General Electric powder camera with a nominal diameter of 143 millimeters. Straumanis technique ${ }^{3}$ was used for correcting for radius and $f i l m-$ shrinkage errors.

The values of the lattice parameters were obtained by extrapolating to $\cos ^{2} \theta=0$ by the method of Bradley and Jay. "The beta polonium was treated as a hexagonal structure, and the results were converted to the rhombohedral structure after all other calculations were made.

The beta-polonium structure was indexed by two methods. The first method followed that of Maxwell and Beamer. ${ }^{2}$ They pointed out that for $\alpha=98^{\circ} 13^{i}$ for the rhombohedral structure several sets of possible powder lines are in coincidence. This occurs for an axial ratio of $c=\sqrt{15 / 16}$ in the hexagonal indexing. The lattice parameters were calculated for the hexagonal and rhombohedral structures with the use of this axial ratio. The axial ratio was also calculated so as to give the best possible fit of the individual lines to the average value of $a_{0}$. The lattice parameters for the hexagonal and rhombohedral structures were calculated with the use of this axial ratio.

The patterns were then rechecked for splitting of some of the 1 ines that would be prohibited by an axial ratio of $c=\sqrt{15 / 16}$. Pattern No. 68-2, which had sharp but spotty 11nes, showed four cases of splitting of these 1 ines. The split was approximately equal in magnitude to the separation of lines observed due to the difference in wavelength of $K_{\alpha_{1}}$ and $K_{\alpha_{2}}$ radiation.

The extrapolated values for the lattice parameter, $a_{0}$, for the hexagonal and cubic cases are given in Table II.

TABLE $\mid$ !

POLONIUM LATTICE PARAMETERS

\begin{tabular}{|c|c|c|}
\hline $\begin{array}{l}\text { PATTERN } \\
\text { NO }\end{array}$ & I NDEXING & $A X \| A L R A T \backslash O$. \\
\hline $51-1$ & HEXAGONAL & $\sqrt{15 / 16}$ \\
\hline 591 & HEXAGONAL & $\sqrt{15 / 16}$ \\
\hline 592 & HEXAGONAL & $\sqrt{15 / 16}$ \\
\hline 681 & HEXAGONAL & $\sqrt{15 / 16}$ \\
\hline 682 & HEXAGONAL & $\sqrt{15 / 16}$ \\
\hline AVERAGE & HEXAGONAL & $\sqrt{15 / 16}$ \\
\hline AVERAGE & RHOMBOHEDRAL & $\alpha=98^{\circ} 13^{\circ}$ \\
\hline 511 & HEXAGONAL & 0.9723 \\
\hline 591 & HEXAGONAL & 0.9723 \\
\hline 59.2 & HEXAGONAL & 0.9723 \\
\hline 681 & HEXAGONAL & 0.9723 \\
\hline 68.2 & HEXAGONAL & 0.9723 \\
\hline AVERAGE & HEXAGONAL & 0.9723 \\
\hline AVERAGE & RHOMBOHEDRAL & $\alpha=98^{\circ} 5^{l}$ \\
\hline 51.2 & SIMPLE CUBIC & \\
\hline 513 & SIMPLE CUBIC & \\
\hline 59.1 & S:MPLE CUBIC & \\
\hline 59.2 & S IMPLE CUB:C & \\
\hline AVERAGE & SIMPLE CUBIC & \\
\hline
\end{tabular}

\begin{tabular}{|c|c|}
\hline 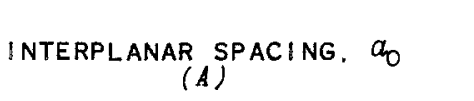 & $\begin{array}{c}\text { STATIST I CAL PROBABLE } \\
\text { ERROR OF AVERAGE, } a_{0} \\
(A)\end{array}$ \\
\hline 5.0906 & \pm 0.0022 \\
\hline 50880 & \pm 0.0025 \\
\hline 5.0870 & \pm 0.0020 \\
\hline 5.0902 & \pm 0.0025 \\
\hline 5.0886 & \pm 0.0011 \\
\hline $\left.\begin{array}{l}5.0889 \\
3.3660\end{array}\right\}$ & $9.406 \mathrm{G} / \mathrm{cc}$ \\
\hline 5.0839 & \pm 0.0005 \\
\hline 5.0840 & \pm 0.0017 \\
\hline 5.0836 & \pm 0.0010 \\
\hline 5.0844 & \pm 0.0005 \\
\hline 5.0836 & \pm 0.0003 \\
\hline $\left.\begin{array}{l}5.0839 \\
3.3660\end{array}\right\}$ & $9.398 \mathrm{G} / \mathrm{CC}$ \\
\hline 3.3593 & \pm 0.0005 \\
\hline 3.3595 & \pm 0.0003 \\
\hline 3.3592 & \pm 0.0004 \\
\hline 3.3595 & \pm 0.0004 \\
\hline DENSITY $=$ & $9.196 \mathrm{G} / \mathrm{CC}$ \\
\hline
\end{tabular}

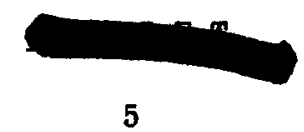


By virtue of the better fit and the fact that splitting of some lines which are in coincidence for $c=\sqrt{15 / 16}$ was observed. the axial ratio of 0.9723 was accepted as the more probable value. This gave, for the hexagonal case, lattice parameters (interplanar spacing and interaxial angles) of $a_{0}=5,0839 A_{0} c_{0}=4,9431 \mathrm{~A}$, and for the rhombohedral case, $a_{0}=3.3660 \mathrm{~A}, \alpha=98^{\circ} 5^{\circ}$. Since there was no question of indexing the patterns of alpha polonium, the lattice parameter could be obtained directly. This value was $a_{0}=3.3594 A_{\text {。 }}$

The X-ray density was computed by calculating the volume of the unit cell from the observed lattice parameters and by calculating the mass inside that volume from the known number of polonium atoms inside the unit cell.

\section{DISCUSSION}

Systematic errors were minimized or reduced by use of the extrapolation method of Bradley and Jay, which eliminated errors due to sample absorption and eccentricity. The use of cameras equipped for the Straumanis technique eliminated errors due to uniform film shrinkage and uncertainty in camera-radius.

There were, however, random errors which were not eliminated Variations of the sample temperature would cause a broadening of the diffraction lines (strains and lattice imperfections also cause broadening) and reduce the accuracy of measurement of these lines. The accuracy of measurement was such that the fourth decimal place was affected even in the backreflection region Nonuniform film shrinkage introduced another random error which may have affected the fourth decimal place

The random error was estimated by calculation of the probable error of the mean value of $a_{0}$. This was $0.0002 \mathrm{~A}$ for both the rhombohedral and the cubic cases. As the systematic errors were included in the data for these calculations, the probable error was actually somewhat smaller than $0.0002 \mathrm{~A}$. The error in $a_{0}$ due to random errors was set at 0.001A. Th1s assured (on a statistical basis) that the true $a_{0}$ had a 99 per cent chance of falling within that error.

The temperature of the sample could not be determined because of the internal heating of the polonium. Previous work ${ }^{5}$ has shown that the temperature of the phase change is $36^{\circ} \mathrm{C}$ and that the two phases may coexist between $18^{\circ}$ and $54^{\circ} \mathrm{C}$. Since both phases were present in the patterns used for this study, the temperature of the sample was between room temperature $\left(24^{\circ} \mathrm{C}\right)$ and $54^{\circ} \mathrm{C}$. Setting the sample temperature at $39^{\circ} \mathrm{C}$ allowed $15^{\circ} \mathrm{C}$ uncertainty in the temperature of the sample Previous work ${ }^{6}$ on the coefficient of expansion has shown that for the alpha phase $a$ is $24 \times 10^{-6}$ centimeter per centimeter per degree from $-196^{\prime}$ to $30^{\circ} \mathrm{C}$. If this figure is used for both phases, a temperature uncertainty of $15^{\circ} \mathrm{C}$ would lead to an uncertainty of approximately $0,001 \mathrm{~A}$ in the lattice parameters

The total uncertainty in the lattice parameters is the sum of that due to random errors and that due to temperature uncertainty, The total uncertainty is, then, $0,002 \mathrm{~A}$.

\section{CONCLUSIONS}

On the basis of the discussion, the computed values for the lattice parameters and densities of polonium are 


$$
\begin{gathered}
\text { Simple Cubic Indexing }-\alpha \text {-polonium } \\
a_{0}=3.359 \pm 0.002 \mathrm{~A} \text { at } 39^{\circ} \mathrm{C} \\
\rho=9.196 \pm 0.006 \mathrm{~g} / \mathrm{cc}
\end{gathered}
$$

Rhombohedral Indexing - $\beta$-polonium

$$
\begin{aligned}
a_{0} & =3.366 \pm 0.002 \mathrm{~A} \text { at } 39^{\circ} \mathrm{C} \\
\alpha & =98^{\circ} 5^{\prime} \pm 2^{\prime}
\end{aligned}
$$

Hexagonal Indexing - $\beta$-polonium

$$
\begin{aligned}
a_{0} & =5.084 \pm 0.003 \mathrm{~A} \text { at } 39^{\circ} \mathrm{C} \\
c_{0} & =4.943 \pm 0.003 \mathrm{~A} \\
\rho & =9.398 \pm 0.006 \mathrm{~g} / \mathrm{cc}
\end{aligned}
$$

\section{REFERENCES}

1. Rollier, M. A., Hendricks, S. B., and Maxwell, L. R., J. Chem. Phys, , 4, 648 (1936).

2. Beamer, W. H. and Maxwell, C. K., J. Chem. Phys. 17, 1293 (1949).

3. Straumanis, $M_{0}$ and Ievins, A., Naturwiss, 23,833 (1935).

4. Bradley, A. J。 and Jay, A. H., Proc. Phys. Soc. (London) 44, 563 (1932).

5. Goode, J. M. The Temperature of the Phase Transitions of Polonium, MLM-615, October 1, 1951 .

6. Goode, J. M。, Rpt。Gen。Res., MLM-484-1, g 1-55, September 11, 1950. 